\title{
Analisis Spasial Respon Bendungan terhadap Model Peak Ground Acceleration (PGA) Berdasarkan Karakteristik Mikrotremor, Geologi Regional dan Amatan Instrumentasi pada Bendungan Sermo Kulonprogo
}

\author{
Nugroho Budi Wibowo' dan Arif Gunawan ${ }^{2}$ \\ ${ }^{1}$ Badan Meteorologi Klimatologi dan Geofisika \\ ${ }^{2}$ Kementerian Pekerjaan Umum \\ nugrohobudiwibowo@gmail.com
}

Received 03-03-2014, Revised 12-05-2014, Accepted 24-06-2014, Published 31-10-2014

\section{ABSTRACT}

This study is a comprehensive-descriptive analysis elaboration to seismic hazards on Sermo Dam, while in terms of microtremor characteristic (PGA model), its regional geology and observation of instrumentation on it. Sermo Dam is the only one water resources infrastructure which lies in The Yogyakarta Province at time of earthquake disaster happened on May 2006. Basic theories used in this case are HVSR methods, determining sediment thickness, and Kanai Method for Maximum Ground Acceleration, Then, based on these we can analyze characteristics of responsiveness damin the form of local spatial region focused by amplitude (A), dominance frequency (fo), time period (T), sediment thickness (H) and Peak Ground Acceleration (PGA) based on microtremor approarch with seismograph TDS 303S. Besides, by an analysis on regional geology that can be obtainable the characteristic of Sermo Dam foundation which lies on the Old Andesite (Kebo Butak) Formation. They are relatively robust when subjected to seismic vibration of middle class to below (less than 7 Richter scale on design). Also it has some declining periodic trends by main dam whereas there is still in the initial stage of design tolerance. The final result is zoning classification of damage potential with: (1) region by PGA values of $0.04 \leq \mathrm{a}<0.15 \mathrm{~g}$ which they are minor impact damage on their buildings; (2) region by PGA values of $0.15 \leq \mathrm{a}<0.34 \mathrm{~g}$ which they are medium impact damage on their buildings. The damage level is comparable by inclining of filler material thickness at dam site.

Keywords: dam responsiveness, geology, instrumentation, microtremor, PGA,Sermo, seismograph

\section{ABSTRAK}

Studi ini merupakan suatu kajian deskripsi komprehensif terhadap potensi bahaya seismik Bendungan Sermo ditinjau dari karakteristik mikrotremor (dalam bentuk model PGA), geologi regionalnya serta analisis terhadap hasil amatan instrumentasi yang ada pada bendungan tersebut (diwakili oleh seismograph-inclinometer-settlement gauge).Bendungan Sermo merupakan satusatunya aset infrastruktur sumber daya air yang berada di Provinsi DI Yogyakarta yang saat gempa Mei 2006 lalu sempat mengalami guncangan gempabumi, namun tidak berdampak serius. Dasar teori yang digunakan pada kasus ini adalah dengan menggunakan metode-metode : Horizontal to Vertical Ratio (HVSR), penentuan ketebalan sedimen (H), dan Kanai untuk Maximum Ground Acceleration. Selanjutnya berdasarkan dari ketiga teori tersebut kita dapat menganalisis karakteristik daya respon bendungan dalam bentuk local-spasial di wilayah tersebut dengan fokus pada komponen Amplitudo (A), frekuensi dominan (fo), periode ukur (T), ketebalan sedimen/material isi di sekitar bendungan, dan Peak Ground Acceleration (PGA) berdasarkan pendekatan mikrotremor menggunakan seismograph TDS 303S. Selain itu, berdasarkan pada analisis geologi regional diperoleh karakteristik pondasi Bendungan Sermo berada pada Formasi Andesit tua /Kebo Butak 
yang relatif kokoh saat dikenai getaran seismik skala menengah ke bawah ( $<$ SR-desain) serta adanya kecenderungan penurunan secara berkala dari tubuh bendungan namun masih dalam taraf toleransi desain awalnya. Hasil akhirnya berupa zonasi klasifikasi potensi kerusakan: (1) daerah dengan nilai PGA $0,04 \leq$ a $<0,15$ gmerupakan daerah ringandampak kerusakan bangunannya; (2) daerah dengan nilai PGA $0,15 \leq \mathrm{a}<0,34 \mathrm{~g}$ berada pada daerah dengan potensi kerusakan sedang Tingkat kerusakan ini sebanding dengan semakin menebalnya material pengisi wilayah sekitar lokasi bendungan.

Kata Kunci : respon bendungan, geologi, instrumentasi, mikrotremor, PGA, Sermo, seismograph

\section{PENDAHULUAN}

Bendungan merupakan salah satu bentuk bangunan air yang memiliki fungsi sebagai penampung air untuk sistem pengairan/irigasi, pembangkit listrik tenaga air, pengolahan air baku dan tempat wisata. Bendungan Sermo terletak di Kali Ngrancah (Sungai Ngrancah), DusunSermo, Desa Hargowilis, Kecamatan Kokap Kabupaten Kulonprogo dan diresmikan pada tanggal 20 November 1996 setelah fase konstruksi selama 32 bulan (1994-1996). Ditinjau dari aspek konstruksinya dan klasifikasi ICOLD (International Commission on Large Dam), Bendungan Sermo merupakan salah satu tipe bendungan urugan batu berzona dengan inti kedap air (rockfill dam with inclined core) dengan kapasitas volume air sebanyak

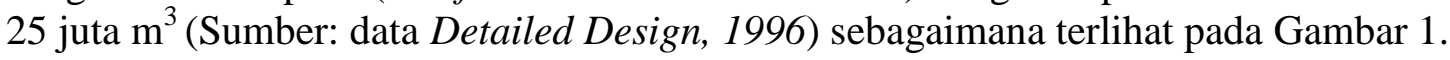

Bendungan memiliki fungsi yang penting sehingga keberlanjutan fungsinya perlu dijaga.Bendungan Sermo secara geologi berada pada Formasi Andesit tua atau Formasi Kebo-Butak (berumur Oligosen atas hingga Miosen tengah atau Oligo - Miosen) yang diendapkan secara tidak selaras di atas Formasi Nanggulan dan berada dekat dengan jalur sesar.Terkait dengan kejadian bencana gempa tahun 2006 yang lalu, keberadaan Bendungan Sermo berlokasi pada daerah yang sangat rawan terimbas dampak seismik.Untuk itu, maka dibutuhkan adanya kajian terhadap sejauhmana respon bendungan tersebut dalam menghadapi potensi seismisitas saat ini dan di masa mendatang.Potensi bahaya seismik ini dapat didekati dengan pengukuran mikrotremor dan kajian geologi regional sekitar Bendungan Sermo.

Penelitian ini bertujuan mengetahui potensi bahaya seismik dengan menganalisa respon bendungan terhadap model PGA (Peak Ground Acceleration), karakteristik geologi regional dan analisis terhadap hasil amatan instrumentasi bendungannya. Bagian dari tubuh bendungan (puncak, kaki dan penyangga) yang memiliki potensi keruksan dapat diketahui lebih dahulu, sehingga tindakan pencegahan dan pengurangan resiko kerusakan dapat ditentukan. 


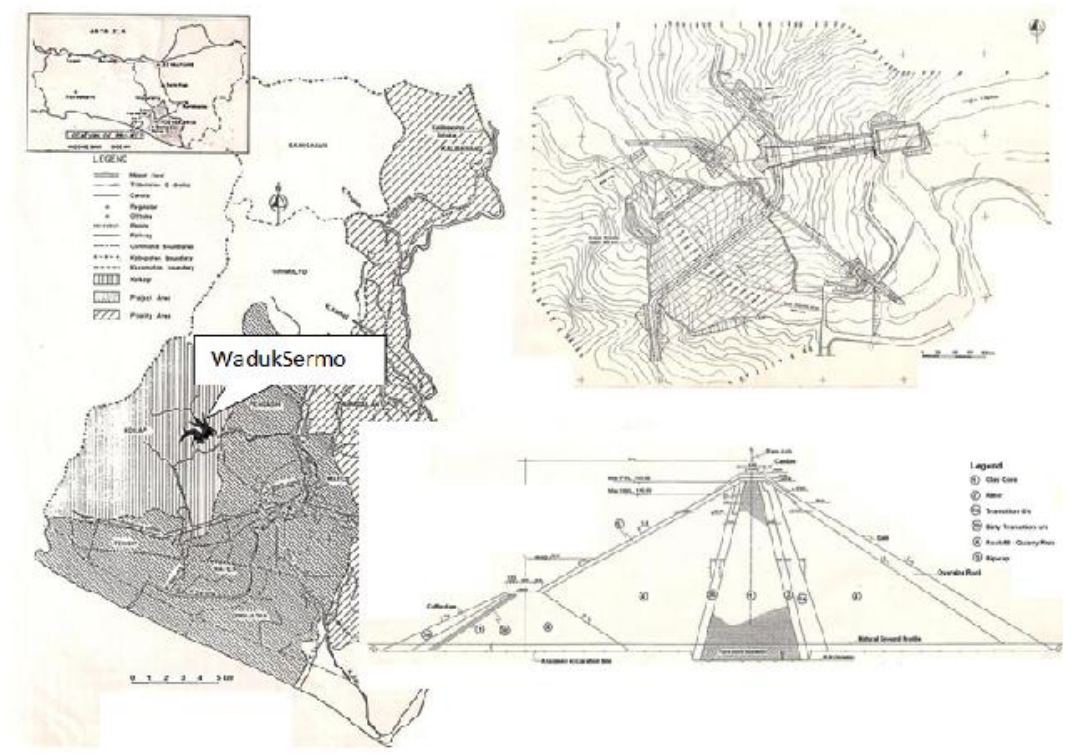

Gambar 1. (color online) Lokasi Bendungan Sermo dan Layout serta Penampangnya ${ }^{[1]}$

\section{METODE}

\section{HVSR (Horizontal to}

\section{Vertical Ratio)}

Ditinjau dari teorinya, persamaan HVSR untuk getaran terukur di permukaan dinyatakan :

$\boldsymbol{H V S R}=\frac{\sqrt{\left(A_{(U-S)}(f)\right)^{2}+\left(A_{(B-T)}(f)\right)^{2}}}{\left(A_{(V)}(f)\right]}$

HVSR = Horizontal to Vertical Ratio

$A_{(U-S)}(f)=$ Nilai Amplitudo spektrum frekuensi komponen Utara-Selatan

$A_{(B-T)}(f)=$ Nilai Amplitudo spektrum frekuensi komponen Barat-Timur

$\left(\boldsymbol{A}_{(\mathrm{V})}(f)\right) \quad=$ Nilai Amplitudo spektrum frekuensi komponen Vertikal

\section{sedimen tanah $(H)$}

Ketebalan lapisan

Dari rasio spektra H/V dapat dihitung ketebalan sedimen yang ada yakni dengan:

$H=V s / 4 f o$

dimana :

$H$ (ketebalan dalam $m$ ), Vs (kecepatan gelombang sekunder dalam $m / s$ ) dan fo (frekuensi dominan dalam $\mathrm{Hz}$ )

- Percepatan tanah maksimum (PGA)

Penentuan model percepatan tanah ini menggunakan metode Kanai (1966), yakni:

$u_{g}=\frac{5}{\sqrt{T_{0}}} 10^{0.61 M-\left(1.66+\frac{3.6}{R}\right) \log R+0.67-\frac{1.83}{R}}$ 
dimana :

$a_{g}$ (PGA dalam gal), To (periode dominan tanah dalam second), M (Magnitude dalam Skala Richter) dan R (jarak hypocenter dalam $\mathrm{km}$ ).

Penelitian ini dilakukan dengan menggunakan pengukuran mikrotremor pada 11 (sebelas) titik amatan di sekitar Bendungan Sermo, data geologi regional Bendungan Sermo dan data hasil amatan instrumen (seismograph-inclinometer-settlement gauge) pada tubuh bendungan. Pengukuran mikrotremor menggunakan TDS-303 portabel seismograph, kompas geologi, GPS, dan Laptop. Standar operasional pengukuran alat tersebut berdasarkan pada SESAME European research project ${ }^{[2]}$ dengan durasi pengukuran 30 menit untuk setiap titiknya. Pengolahan data menggunakan softwareNetRec, DataPro, Geopsy, Surfer, Global Mapper dan Google Earth. Metode pengolahan data mikrotremor menggunakan metode HVSR (Horizontal to Vertical Ratio) untuk mengghasilkan variabel utama berupa data frekuensi dominan ( $f o$ ) dan faktor amplifikasi $(A)$. Variabel utama tersebut diturunkan untuk menghasilkan nilai ketebalan sedimen $(H)$ dan percepatan tanah $(P G A)$. Studi kasus yang digunakan adalah peristiwa bencana gempabumi Yogyakarta 27 Mei 2006 yang lalu. Data hasil pengolahan mikrotremor dikomparasi dengan analisa data geologi dan hasil amatan instrumen pada tubuh bendungan.

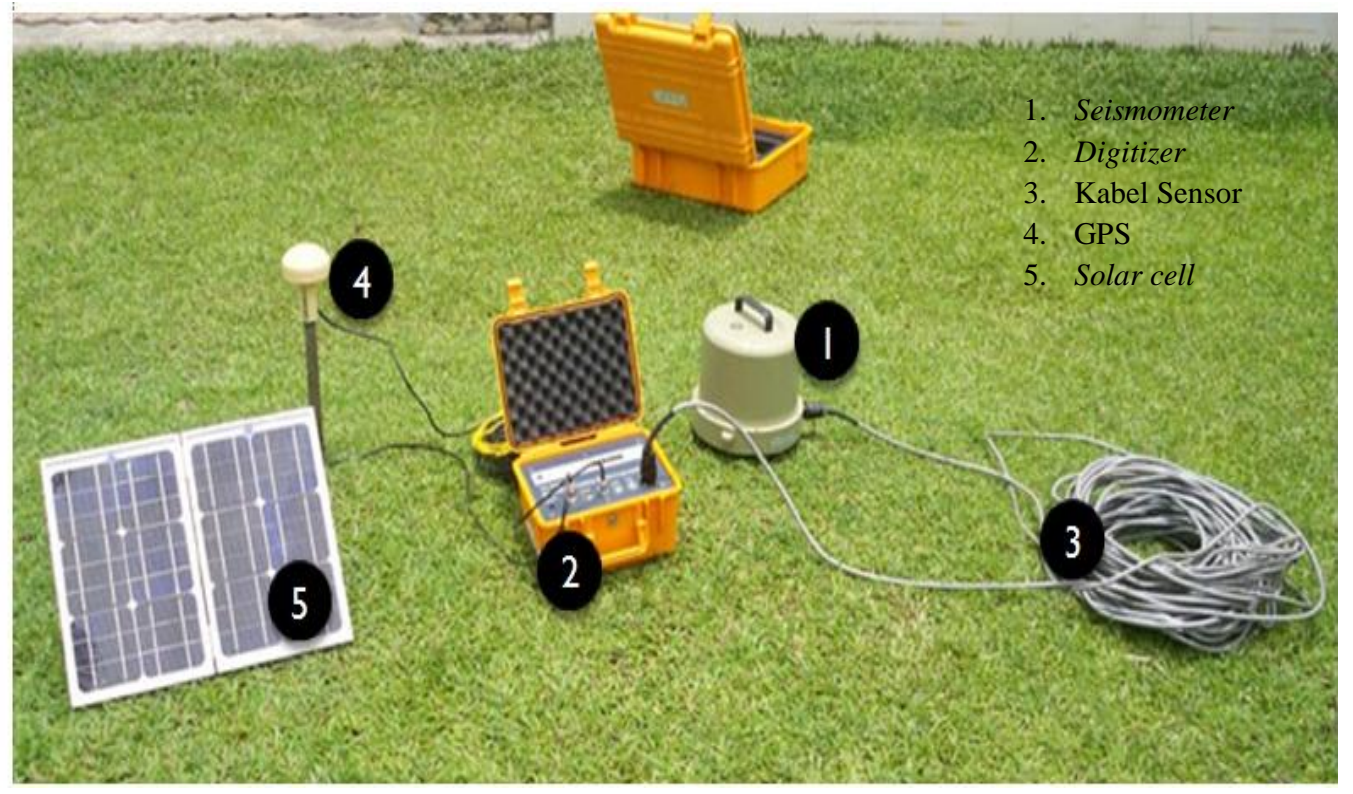

Gambar 2. (color online) Portabel Seismograph TDS 303S 


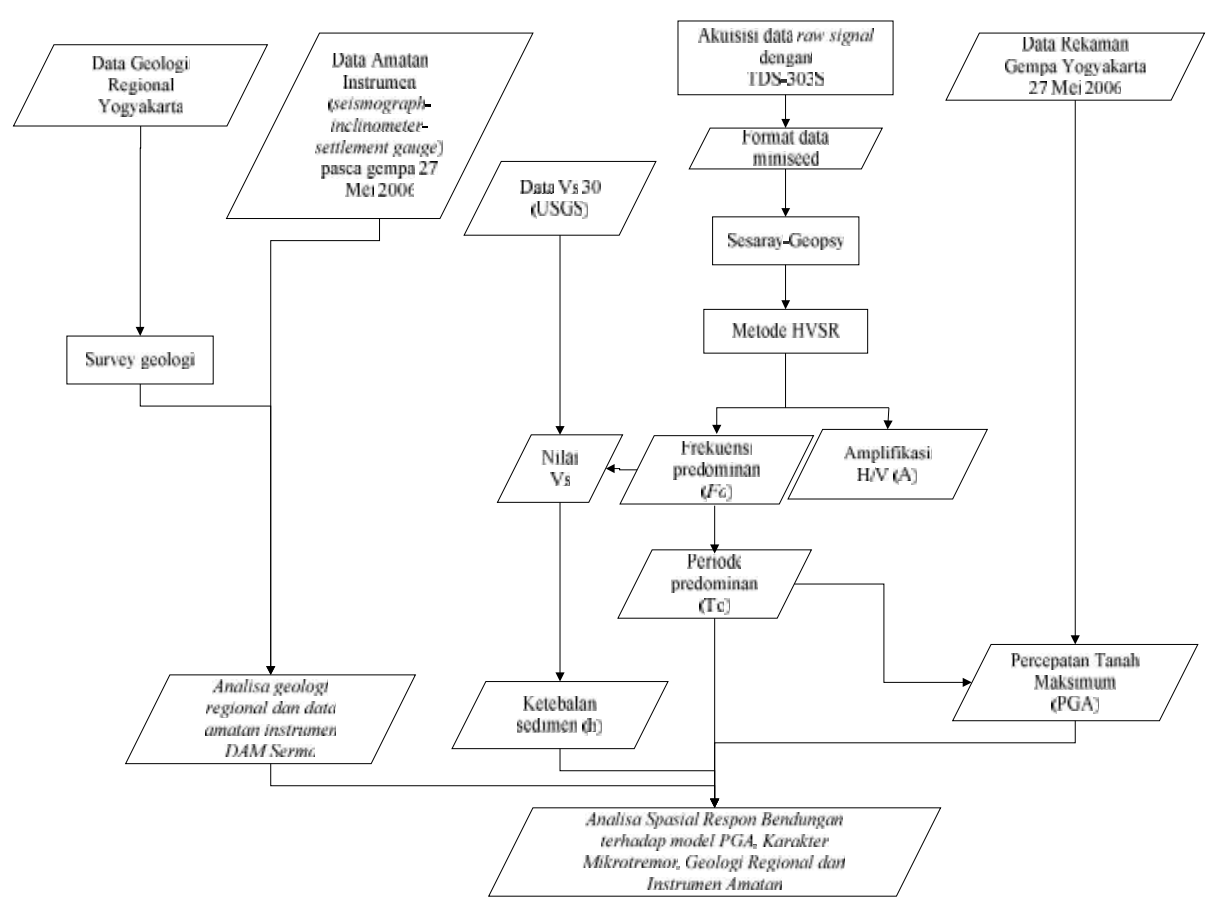

Gambar 3. Diagram alir penelitian

\section{HASIL DAN PEMBAHASAN}

\section{Karakteristik Mikrotremor Bendungan Sermo Kulonprogo}

Bendungan Sermo terletak di Kali Ngrancah, Dusun Sermo, Desa Hargowilis, Kecamatan Kokap, Kabupaten Kulonprogo dan diresmikan pada tanggal 20 November 1996. Bendungan Sermo memiliki tipe bendungan urugan batu dengan inti tanah yang dapat menampung volume air sebanyak 25 juta $\mathrm{m}^{3}$.Pengukuran mikrotremor pada Bendungan Sermo bertujuan untuk mengetahui karakteristik mikrotremor pada tubuh bendungan dan wilayah sekitarnya. Pengolahan data mikrotremor menggunakan metode HVSR. Variabel yang dihasilkan dari pengolahan data adalah data frekuensi dominan tanah $(f o)$, faktor amplifikasi $(A)$, periode dominan tanah (To), dan ketebalan sedimen $(h)$. Variabel frekuensi dan periode dominan tanah menunjukkan karakteristik material penyusun lapisan. Hasil pengukuran dan pengolahan data menunjukkan material penyusun tubuh bendungan merupakan material lunak dengan variasi frekuensi dominan $1,04-1,50 \mathrm{~Hz}$ dan periode dominan 0,67-0,96s. Identifikasi material lunak berdasarkan klasifikasi tanah konversi kanai \& tanaka dengan omote-nakajima ${ }^{[3]}$ dan sesuai dengan kondisi yang ada di lapangan seperti pada Gambar 2.c. menunjukkan material utama penyusun tubuh bendungan berupa tanah lempung (batulempung) coklat kemerahan. Zonasi frekuensi dan periode dominan memberikan informasi kondisi disekitar bendungan yang tersusun atas material batuan keras dengan variasi frekuensi $8,00-10,16 \mathrm{~Hz}$ dan $0,09-0,13 \mathrm{~s}$. Nilai tersebut merupakan kisaran yang diperoleh dari hasil pengukuran detil di lokasi.Hal ini yang menjadi salah satu parameter utama kajian ini. Sedangkan ketebalan lapisan sedimen berdasarkan model mikrotremor bervariasi dari $12-94$ m. Kemudian untuk faktor amplifikasi yang terdapat di sekitar bendungan berada pada variasi amplifikasi rendah sampai dengan sedang, yaitu 1,03-4,94. 


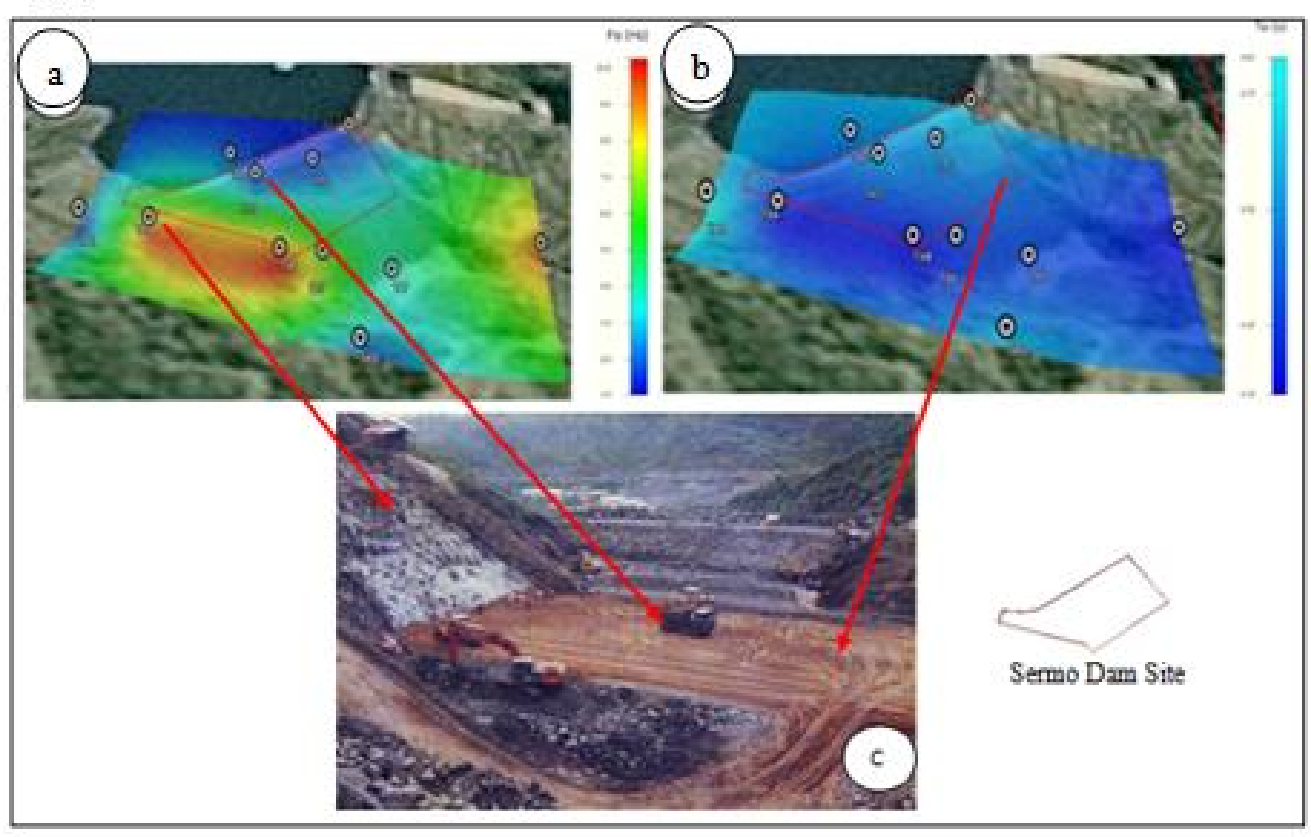

Gambar 4. (color online) a. variasi frekuensi dominan tanah (fo), b. variasi periode dominan tanah (To) di tubuh Bendungan Sermo dan c. foto proses pembangunan bendungan ${ }^{[1]}$.

Lapisan sedimen paling tebal terdapat pada kawasan tubuh bendung dan waduk. Karakteristik mikrotremor berdasarkan variabel faktor amplifikasi dan ketebalan sedimen menunjukkan hubungan yang linear, dimana semakin tebal lapisan maka faktor amplifikasi pada lokasi tersebut juga meningkat. Hal ini menunjukkan bahwa kawasan dengan lapisan yang tebal dan faktor ampifikasi yang tinggi akan memberikan respon getaran/goncangan lebih lama dan besar jika terjadi gempabumi atau sumber getar buatan.

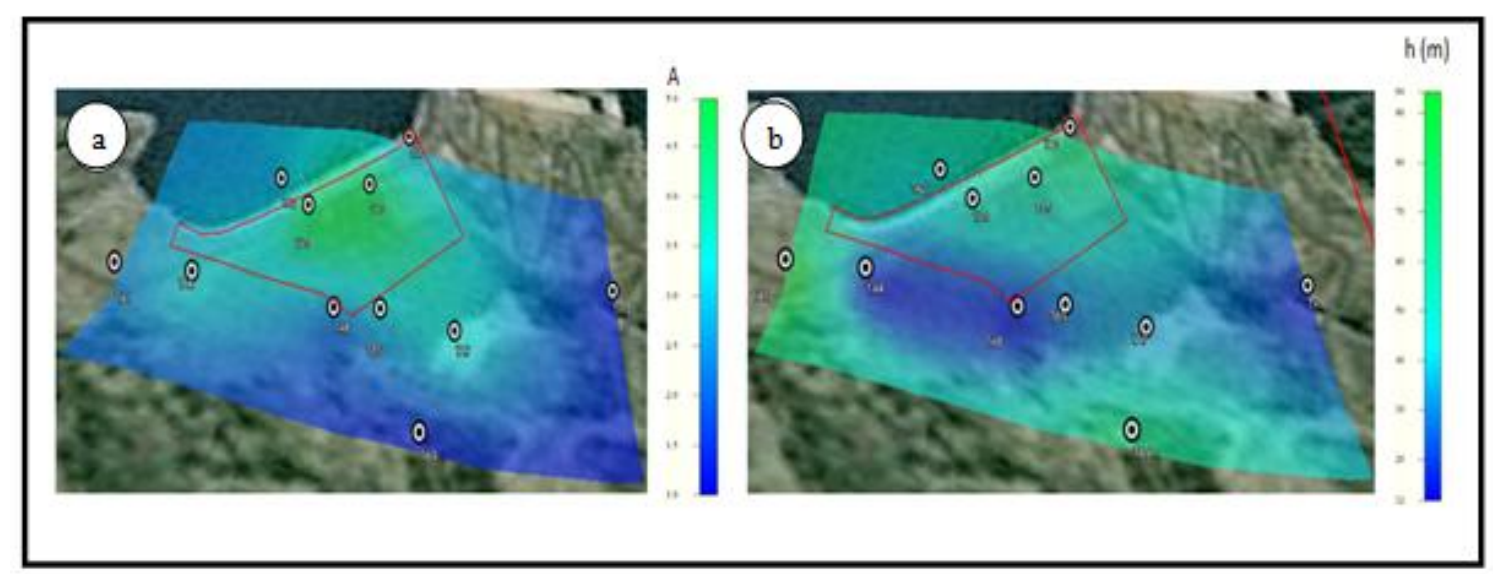

Gambar 5. (color online) a. Variasi nilai faktor amplifikasi $(A)$ dan b. Variasi ketebalan sedimen/tanah $(h)$ 


\section{Karakteristik Geologi Regional dan Tinjauan Hasil Amatan Instrumentasi pada Bendungan Sermo (Kulonprogo)}

Bendungan Sermo berada pada salah satu kaki lembah pada Pegunungan Kulonprogo. Kajian stratigrafi regional mendapatkan data bahwa telah terdapat adanya rekaman proses aktivitas tektonisme yang intensif setidaknya selama periode Tersier -Kuarter awal (antara 100.000 hingga 20.000 tahun yang lalu), khususnya Pegunungan Kulonprogo, dengan ditandai jalur-jalur patahan akibat respon proses pengangkatan yang telah terjadi ${ }^{[4]}$. Dan dengan adanya jalur - jalur zonasi sesar ini sangat dimungkinkan untuk teraktivasi kembali oleh pengaruh tektonisme seperti diakibatkan oleh subduksi Lempeng Indo-Australia terhadap Lempeng Eurasia (Pulau Jawa). Van Bemmelen (1949) telah merekonstruksi keberadaan Pegunungan Kulonprogo dengan sketsa block diagram sebagai dome (kenampakan morfologi berbentuk kubah) dalam proses tektoniknya ${ }^{[8]}$. Dimana puncak dari dome ini merupakan plateau Jonggrangan pembentuk Formasi Jonggrangan (formasi ini berada di atas Formasi Andesit tua). Kubah ini oleh van Bemmelen sebagai kubah yang memanjang dari arah barat daya hingga timur laut dengan panjang sekitar $32 \mathrm{~km}$ dan melebar hingga $15-20 \mathrm{~km}$ arah tenggara - barat laut. Dan pada kaki-kaki dome tersebut dijumpai pola zonasi sesar (normal dan naik) dengan arah radial (Gambar 4). Adanya zonasi patahan tersebut yang kemudian menjadi perhatian utama saat kegiatan pembangunan Bendungan Sermo di tahun 1994 - 1996. Rekaman kerusakan minor bendungan ini akibat bencana gempabumi fenomenal pada tanggal 27 Mei 2006 yang lalu setidaknya semakin memperkuat hipotesis bahwa timbul kerentanan bangunan utama Bendungan Sermo sebagai salah satu infrastruktur vital terhadap bahaya seismik / tektonik menjadi fokus penelitian ini.

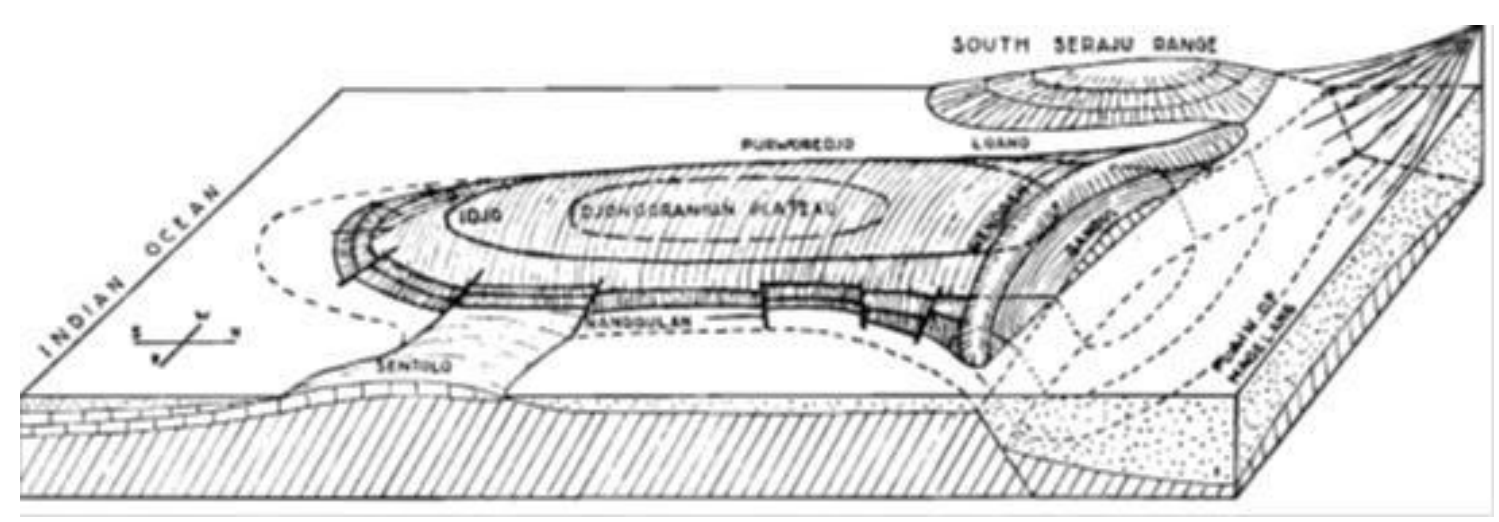

Gambar 6. Block Diagram Pegunungan Kulonprogo ${ }^{[8]}$

Ditinjau dari aspek geologi regionalnya, maka pada umumnya pondasi tubuh bangunan utama Bendungan Sermo berada pada Formasi Andesit tua atau Formasi Kebo-Butak (berumur Oligosen atas hingga Miosen tengah atau Oligo - Miosen) yang diendapkan secara tidak selaras di atas Formasi Nanggulan ${ }^{[4]}$. Adapun komposisi litologinya terdiri dari breksi vulkanik dengan fragmen andesit, lapilli-tuf, tuf, lapili, hingga sisipan aliran lava andesit/aglomerat hingga batupasir. 


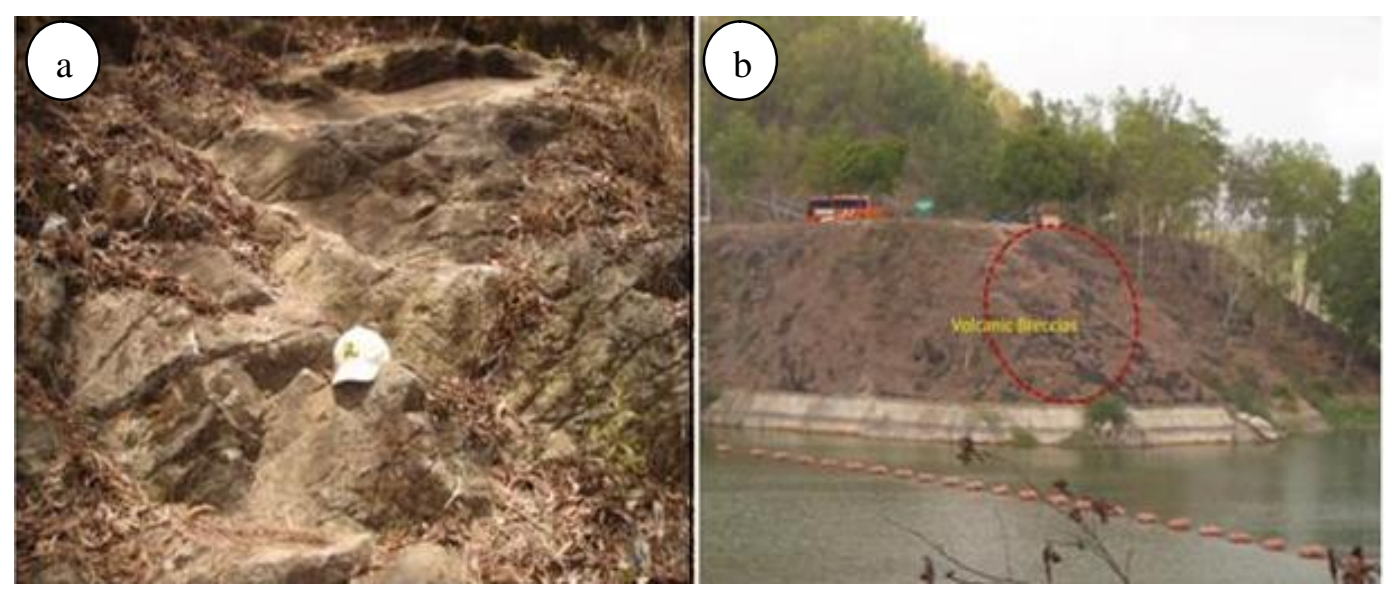

Gambar 7. (color online) a. Singkapan Batuan Andesit (Formasi Kebo Butak) pada abutment kanan Bendungan Sermo dan b. Singkapan Breksi Vulkanik (Formasi Kebo Butak) pada salah satu tebing waduk.

Pelamparan formasi ini dapat ditemukan di bagian utara, tengah dan barat daya Kulonprogo yang membentuk geomorfologi pegunungan bergelombang dengan slope antara $15^{\circ}-45^{\circ}$ dan ketebalan formasinya hingga kira - kira mencapai $600 \mathrm{~m}$. Sedangkan lokasi daerah genangan waduknya berada di Formasi Nanggulan yang didominasi oleh batupasir kuarsa dan batulempung yang mengandung fosil - fosil Mollusca. Gambar 7.a dan b menunjukkan beberapa singkapan batuan yang merupakan material penyusun wilayah di sekitar lokasi bendungan utama dan pada daerah genangan waduk.

Pemasangan peralatan instrumentasi pada Bendungan Sermo termasuk kompleks karena terdiri dari berbagai jenis dan memiliki fungsi yang berbeda satu dengan yang lainnya. Dan terkait dengan antisipasi terhadap bahaya seismik yakni dengan pemasangan alat Seismograph (Strong Motion Seismograph) pada tubuh bendungan utama untuk mengetahui adanya gerakan yang diakibatkan gempa besar dengan kekuatan dan waktu terjadi gempa yang tercatat pada alat tersebut dan dikombinasikan oleh inclinometer dan settlement gauge yang masing-masing ditujukan bagi pemantauan pergerakan secara horizontal di dalam tubuh bendungan pada timbunan tanah inti maupun timbunan batu, pergerakannya kearah kiri - kanan maupun arah hulu dan hilir serta untuk mengetahui pergerakan penurunan timbunan dalam tubuh bendungan secara vertikal baik di timbunan tanah inti maupun pada timbunan batu. Pada Bendungan Sermo setidaknya dapat disajikan karakteristik kondisinya sejak tahun 1996 (peresmian fungsinya) berdasarkan pada observation point $(O P)$ sebagaimana tercantum pada Tabel 1. Berdasarkan hasil amatan terhadap instrumentasi settlement gauge tersebut, tampak bahwa sejak pasca konstruksi di akhir tahun 1996 hingga mendekati waktu terjadinya bencana gempabumi di tahun 2006 (27 Mei) berkecenderungan stabil. Namun sejak terjadinya gempa, data pengamatan menunjukkan mulai terjadi penurunan secara berkala meskipun masih dalam taraf toleransi perhitungan desain awalnya (lihat grafik tabel 1 dan lampiran tabel settlement gauge dan chart St1-2-3). Desain bendungan ini disesuaikan dengan kondisi hingga sekitar 7,0 SR ${ }^{[3]}$. 
Tabel.1. Hasil amatan instrumentasi (terpilih) yang menjelaskan karakteristik Bendungan Sermo pasca konstruksi hingga beberapa tahun setelah gempa $2006^{[2]}$.

PENGAMATAN GERAKAN VERTIKAL PERMUKAAN TUBUH BENDUNGAN SERMO SEBELAH AS DAM

\begin{tabular}{||c|c|c|c|c|c|c|c||}
\hline STA. & $\mathbf{7}$ & $\mathbf{9 . 5}$ & $\mathbf{1 2}$ & $\mathbf{1 4 . 5}$ & $\mathbf{1 7}$ & $\mathbf{1 9 . 5}$ & $\mathbf{2 2}$ \\
\hline \hline & $\mathbf{O P 2}$ & $\mathbf{O P 5}$ & $\mathbf{O P 8}$ & $\mathbf{O P 1 1}$ & $\mathbf{O P 1 4}$ & $\mathbf{O P 1 7}$ & OP20 \\
\hline \hline 8-Oct-96 & $\mathbf{1 4 1 . 9 5 3}$ & $\mathbf{1 4 2 . 2 0 5}$ & $\mathbf{1 4 2 . 4 5 4}$ & $\mathbf{1 4 3 . 0 7 4}$ & $\mathbf{1 4 3 . 0 5 6}$ & $\mathbf{1 4 2 . 4 1 7}$ & $\mathbf{1 4 2 . 1 7 2}$ \\
\hline 15-Mar-06 & 141.942 & 142.140 & 142.321 & 142.883 & 142.858 & 142.274 & 142.085 \\
\hline 29-May-06 & 141.941 & 142.138 & 142.317 & 142.881 & 142.855 & 142.264 & 142.077 \\
\hline 13-Jun-06 & 141.937 & 142.134 & 142.322 & 142.881 & 142.851 & 142.266 & 142.088 \\
\hline 10-Jul-06 & 141.939 & 142.136 & 142.324 & 142.874 & 142.847 & 142.263 & 142.085 \\
\hline 7-Sep-06 & 141.938 & 142.131 & 142.320 & 142.869 & 142.843 & 142.261 & 142.075 \\
\hline 14-Oct-06 & 141.935 & 142.133 & 142.309 & 142.868 & 142.848 & 142.260 & 142.086 \\
\hline 1-Dec-06 & 141.936 & 142.131 & 142.313 & 142.860 & 142.832 & 142.253 & 142.082 \\
\hline 25-Jan-07 & 141.939 & 142.128 & 142.304 & 142.852 & 142.822 & 142.246 & 142.086 \\
\hline 27-Mar-07 & 141.936 & 142.122 & 142.302 & 142.847 & 142.822 & 142.248 & 142.081 \\
\hline 29-Aug-07 & 141.937 & 142.124 & 142.307 & 142.847 & 142.821 & 142.249 & 142.081 \\
\hline 28-Nov-07 & 141.937 & 142.123 & 142.299 & 142.844 & 142.819 & 142.246 & 142.077 \\
\hline 30-Jan-08 & 141.937 & 142.123 & 142.299 & 142.844 & 142.819 & 142.246 & 142.077 \\
\hline 29-Apr-08 & 141.937 & 142.126 & 142.305 & 142.848 & 142.824 & 142.268 & 142.106 \\
\hline 31-Jul-08 & 141.937 & 142.123 & 142.301 & 142.847 & 142.817 & 142.243 & 142.077 \\
\hline 29-Oct-08 & 141.935 & 142.119 & 142.296 & 142.846 & 142.817 & 142.242 & 142.075 \\
\hline 28-Jan-09 & 141.935 & 142.121 & 142.296 & 142.840 & 142.819 & 142.243 & 142.073 \\
\hline 24-Apr-09 & 141.934 & 142.120 & 142.298 & 142.841 & 142.817 & 142.244 & 142.073 \\
\hline 17-Ju1-09 & 141.932 & 142.118 & 142.294 & 142.836 & 142.812 & 142.240 & 142.068 \\
\hline 16-Dec-09 & 141.934 & 142.117 & 142.294 & 142.837 & 142.815 & 142.227 & 142.058 \\
\hline 1-Apr-10 & 141.924 & 142.105 & 142.301 & 142.822 & 142.795 & 142.254 & 142.084 \\
\hline 14-Apr-11 & 141.937 & 142.124 & 142.292 & 142.841 & 142.817 & 142.239 & 142.068 \\
\hline 6-Jun-12 & 141,936 & 142124 & 142292 & 142841 & 142819 & 142239 & 142067 \\
\hline Penurunan(m) & $-\mathbf{0 . 0 1 6}$ & $-\mathbf{0 . 0 8 1}$ & $-\mathbf{0 . 1 6 2}$ & $-\mathbf{0 . 2 3 3}$ & $-\mathbf{0 . 2 3 9}$ & $-\mathbf{0 . 1 7 8}$ & $-\mathbf{0 . 1 0 4}$ \\
\hline \hline
\end{tabular}

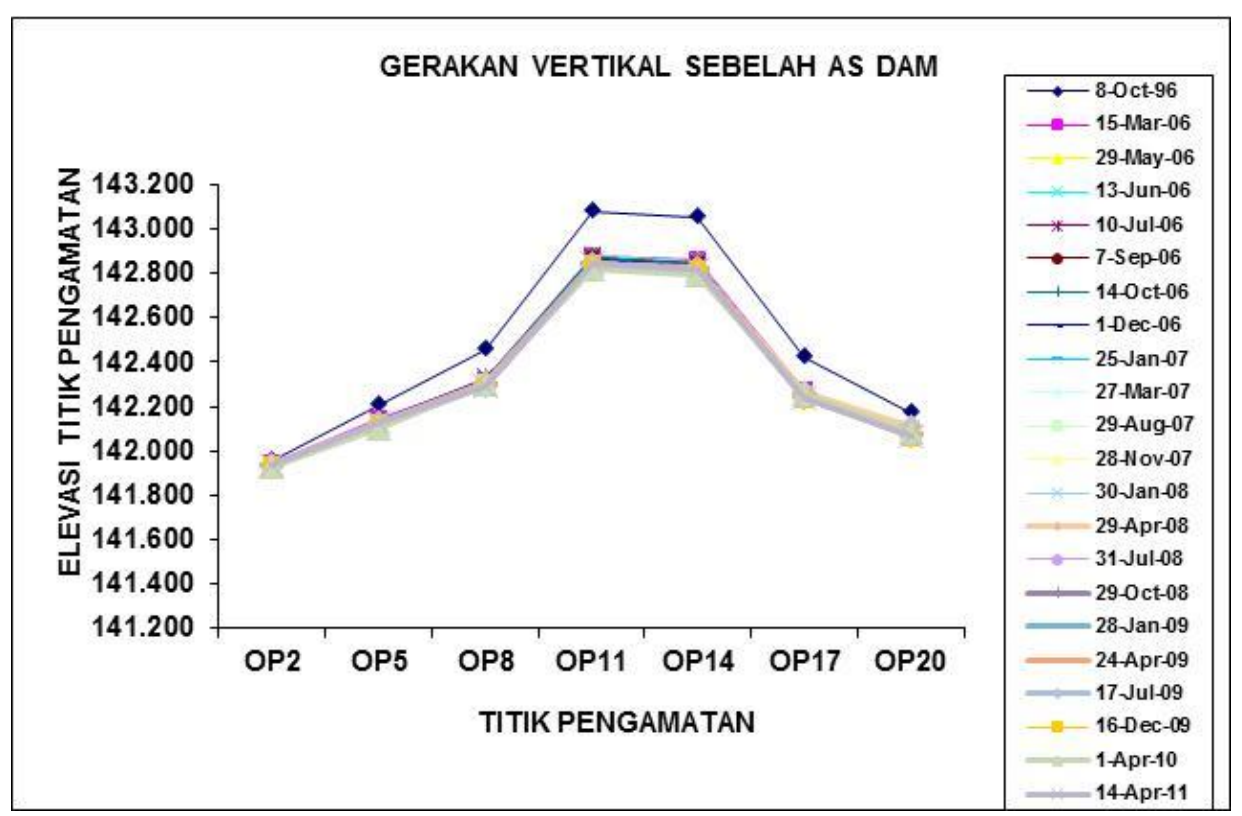




\section{Respon Bendungan berdasarkan Model PGA (Peak Ground Acceleration)}

Potensi bencana di kawasan sekitar bendungan dapat diidentifikasi menggunakan karakteristik mikrotremor untuk menentukan nilai PGA. Studi kasus gempabumi yang digunakan untuk melihat respon bendungan terhadap PGA adalah gempabumi 27 Mei 2006. Gempabumi yang memiliki epicenter 8,26 LS;110,31 BT dengan magnitude 5,9 SR dan kedalaman $33 \mathrm{~km}$ menyebabkan kerusakan yang signifikan di wilayah Yogyakarta dan Jawa Tengah. Model PGA didasarkan pada metode Kanai dengan mempertimbangkan karakteristik periode dominan tanah setempat. Hasil model PGA menunjukkan respon PGA tertinggi sebesar $0,354 \mathrm{~g}$ pada bagian tumpuan dan kaki bendung sisi Barat dan PGA terendah sebesar 0,123 g pada tubuh bendungan sisi Timur.

Berdasarkan klasifikasi potensi kerusakan, model PGA di Bendungan Sermo masuk dalam kategori potensi kerusakan ringan $(0,04 \leq \mathrm{a}<0,15 \mathrm{~g})$ sampai sedang $(0,15 \leq \mathrm{a}<$ $0,34 \mathrm{~g}$ ). Potensi kerusakan sedang terdapat di sisi barat bendungan (sebanding dengan ketebalan material urugan pengisi kaki bendungannya), sedangkan di tubuh bendungan potensi kerusakannya ringan. Informasi potensi kerusakan yang dihasilkan dari pemodelan PGA, dapat digunakan sebagai salah satu dasar penentuan prioritas pemeliharaan (maintenance) tubuh bendungan dan menjadi acuan pihak pengelola dalam tahapan operasi dan pemeliharaannya (O-P). Aspek O-P ini menjadi hal yang krusial untuk segera diperhatikan penanganannya.

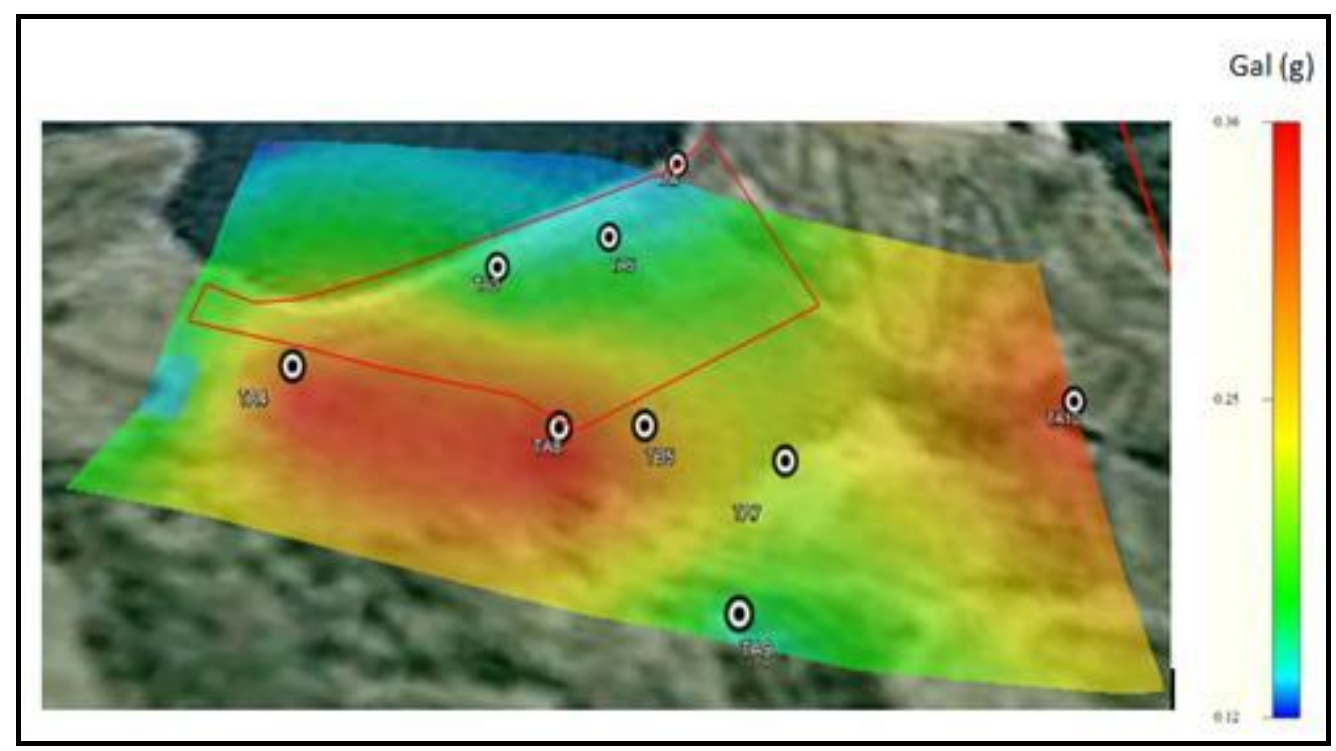

Gambar 8. (color online) Zonasi Klasifikasi Potensi Kerusakan berdasarkan Model PGA di sekitar Bendungan Sermo 


\section{KESIMPULAN}

Material penyusun tubuh bendungan merupakan tanah merah dengan variasi frekuensi dominan 1,04 - 1,50 $\mathrm{Hz}$ dan periode dominan 0,67 - 0,96 s berdasarkan klasifikasi tanah konversi kanai \& tanaka dengan omote-nakajima ${ }^{[7]}$. Faktor amplifikasi yang terdapat di sekitar bendungan berada pada variasi amplifikasi rendah sampai sedang yaitu 1,03 - 4,94 dengan ketebalan lapisan sedimen bervariasi dari 12 - $94 \mathrm{~m}$. Potensi bahaya terhadap getaran seismik berbanding lurus dengan semakin tebalnya sedimen/material urugan pada bendungan. Kajian geologi regional menunjukkan pondasi tubuh bangunan utama Bendungan Sermo berada pada Formasi Andesit tua atau Formasi Kebo-Butak (berumur Oligosen atas hingga Miosen tengah atau Oligo - Miosen). Karakteristik formasi ini secara umum bersifat getas dan stabil terhadap pengaruh getaran seperti gempabumi. Pasca gempa 27 Mei 2006 telah terjadi kecenderungan adanya penurunan (gerakan vertikal) pada tubuh bendungan secara berkala meskipun masih dalam taraf toleransi perhitungan desain awalnya. Plotting terhadap titik ukur menghasilkan zonasi klasifikasi potensi kerusakan berdasarkan model PGA. Zonasi spasial pada Bendungan Sermo ini termasuk ke dalam kategori potensi kerusakan ringan $(0,04 \leq \mathrm{a}<0,15 \mathrm{~g})$ sampai sedang $(0,15 \leq \mathrm{a}<0,34 \mathrm{~g})$.

\section{DAFTAR PUSTAKA}

1 Balai Bendungan Ditjen SDA Kementerian Pekerjaan Umum, 2012.Diklat Teknis Inspeksi dan Evaluasi Keamanan Bendungan (tidak dipublikasikan).

2 Balai PSDA Sermo BBWS Serayu-Opak., 2012. Hasil Pemantauan Instrumentasi pada Bendungan Sermo (tidak dipublikasikan).

3 Direktorat Jenderal Sumber Daya Air Departemen PU, 1996. Detailed Design of Sermo Dam.

4 Mulyaningsih. 2006. Perkembangan Geologi pada Kuarter Awal sampai Masa Sejarah di Dataran Yogyakarta, Jurnal Geologi Indonesia vol.1 No.2.

5 SESAME. 2004. Guidelines for the implementation of the $h / v$ spectral ratio technique on ambient vibrations measurements, processing and interpretation.

6 Setiawan, J.H., 2008. Mikrozonasi Seismisitas Daerah Yogyakarta dan Sekitarnya, Tesis Magister ITB, Bandung (tidak dipublikasikan).

7 Subardjo, Gunawan I. 2005. Pengetahuan Seismologi. Jakarta: BMKG.

8 Van Bemmelen., 1949. The Geology of Indonesia, vol. 1 A, Martinus Nijhoff, The Hague. 